\title{
Correction to: Review of: Dabbagh, N., Marra, R. M., \& Howland, J. L., (2019). Meaningful Online Learning: Integrating Strategies, Activities, and Learning Technologies for Effective Designs. Routledge
}

Cecil R. Short ${ }^{1} \cdot$ Charles R. Graham $^{1}$

Published online: 25 October 2020

(C) Association for Educational Communications \& Technology 2020

Correction to: TechTrends.

https://doi.org/10.1007/s11528-020-00547-8

The title of the original version of this article unfortunately contained an error. The year should be 2019 shown above. In the reference list, the year for Dabbah, Marra, and Howland should be 2019 .

Publisher's Note Springer Nature remains neutral with regard to jurisdictional claims in published maps and institutional affiliations.

The online version of the original article can be found at https://oi.org/ $10.1007 / \mathrm{s} 11528-020-00547-8$

Charles R. Graham

charles.graham@byu.edu

Cecil R. Short

cecil.r.short@gmail.com

1 Brigham Young University, Provo, UT, USA 